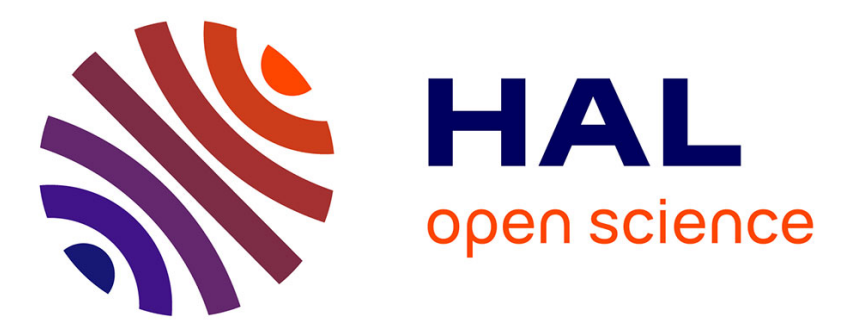

\title{
Prevalence and distribution patterns of seven different honeybee viruses in diseased colonies: a case study from Croatia
}

Ivana Tlak Gajger, Jolanta Kolodziejek, Tamás Bakonyi, Norbert Nowotny

\section{- To cite this version:}

Ivana Tlak Gajger, Jolanta Kolodziejek, Tamás Bakonyi, Norbert Nowotny. Prevalence and distribution patterns of seven different honeybee viruses in diseased colonies: a case study from Croatia. Apidologie, 2014, 45 (6), pp.701-706. 10.1007/s13592-014-0287-0 . hal-01234769

\section{HAL Id: hal-01234769 \\ https://hal.science/hal-01234769}

Submitted on 27 Nov 2015

HAL is a multi-disciplinary open access archive for the deposit and dissemination of scientific research documents, whether they are published or not. The documents may come from teaching and research institutions in France or abroad, or from public or private research centers.
L'archive ouverte pluridisciplinaire HAL, est destinée au dépôt et à la diffusion de documents scientifiques de niveau recherche, publiés ou non, émanant des établissements d'enseignement et de recherche français ou étrangers, des laboratoires publics ou privés. 


\title{
Prevalence and distribution patterns of seven different honeybee viruses in diseased colonies: a case study from Croatia
}

\author{
Ivana Tlak GaJger $^{1}$, Jolanta KolodzIEJEK ${ }^{2}$, Tamás BAKonYI ${ }^{2,3}$, Norbert Nowotny ${ }^{2,4}$ \\ ${ }^{1}$ Department for Biology and Pathology of Fish and Bees, Faculty of Veterinary Medicine, \\ University of Zagreb, Zagreb, Croatia \\ ${ }^{2}$ Viral Zoonoses, Emerging and Vector-Borne Infections Group, Institute of Virology, \\ University of Veterinary Medicine Vienna, Vienna, Austria \\ ${ }^{3}$ Department of Microbiology and Infectious Diseases, Faculty of Veterinary Science, \\ Szent István University, Budapest, Hungary \\ ${ }^{4}$ Department of Microbiology and Immunology, College of Medicine and Health Sciences, \\ Sultan Qaboos University, Muscat, Sultanate of Oman
}

Received 16 October 2013 - Revised 7 March 2014 - Accepted 9 April 2014

\begin{abstract}
The prevalence and regional distribution patterns of seven different honeybee viruses, i.e. Acute bee paralysis virus (ABPV), Sacbrood virus (SBV), Black queen cell virus (BQCV), Deformed wing virus (DWV), Kashmir bee virus (KBV), Chronic bee paralysis virus (CBPV), and Israeli acute paralysis virus (IAPV) were investigated using reverse transcription PCR (RT-PCR) analyses. Bee samples were collected in 82 apiaries located in 20 different districts of Croatia, mainly from bee colonies with various health problems. $9.75 \%$ of investigated samples (apiaries) proved to be infected with CBPV, while ABPV, BQCV, SBV, and DWV were found in $10.97 \%, 29.26 \%, 40.24 \%$, and $95.12 \%$ of apiaries, respectively. No samples tested positive for KBV and IAPV. Thus, the prevalences of BQCV, ABPV, SBV, and CBPV were generally lower in Croatia compared to other European Union member states, whereas the prevalence of DWV was similarly high. The possible reasons for these differences are discussed. This study provides the first molecular evidence for the presence of honeybee viruses in Croatian honeybees.
\end{abstract}

\section{Apis mellifera / winter losses / honeybee viruses / RT-PCR analyses / Croatia}

\section{INTRODUCTION}

Honeybees are an extremely important part of the natural ecosystem because they help to maintain biodiversity and enhance agricultural productivity by providing valuable pollination services, based on the ecological principal of mutual interactions between pollinated plants and pollinators (Delaplane and Mayer 2000;

Corresponding author: I. Tlak Gajger, ivana.tlak@vef.hr

Manuscript editor: Peter Rosenkranz
Gallai et al. 2008). Factors that may contribute to honeybee diseases and mortality include pathogenic microorganisms (Cox-Foster et al. 2007; De Miranda and Genersch 2010; Ribière et al. 2010), climatic parameters (Bailey and Perry 2001), and exposure to pesticides (Antunez et al. 2006; Cresswell et al. 2012). Frequently honeybee viruses persist as inapparent infections (Chen and Siede 2007). In certain cases, however, e.g. when environmental and beekeeping factors result in stress, they may cause clinical symptoms and even lethal disease in bee colonies (Allen and Ball 1996; Nordstrom et al. 1999; Todd et al. 2007; 
Genersch and Aubert 2010). Viral diseases of honeybees are found worldwide and may result in significant economic losses, manifested by colony losses, reduced yields of honey and bee products, and reduced pollination efficiency, resulting in poor quality and reduced yields of agricultural products. Little is known about and there is no literature pertaining to the prevalence of honeybee viruses in Croatia. Croatia very recently became a new member state of the European Union (EU). It borders on the EU member states of Slovenia, Hungary, and Italy, as well as on several non-EU member states with entirely different trade regulations. This unique geographic location makes it especially interesting to investigate the status and regional distribution of honeybee pathogens. The aim of this survey was, therefore, to investigate the presence of the seven most economically important honeybee viruses and to determine their distribution in all twenty districts and all three climatic areas (Mediterranean, mountain, and continental) of Croatia.

\section{MATERIALS AND METHODS}

In this study we investigated the prevalence and regional distribution patterns of the seven most important honeybee viruses, i.e. Acute bee paralysis virus (ABPV), Sacbrood virus (SBV), Black queen cell virus (BQCV), Deformed wing virus (DWV), Kashmir bee virus (KBV), Chronic bee paralysis virus (CBPV), and Israeli acute paralysis virus (IAPV). The distribution of honeybee virus infections was studied in all 20 districts of Croatia (Table I, Figure 1). Bee samples were collected in 82 apiaries, mainly from bee colonies with various health problems like depopulation, weakness, and high colony mortality. Samples of winter losses (from January and February 2010) were collected from the bottoms of beehives during the first spring inspection of honeybee colonies. Each sample consisted of approximately 100 bees, representing one location or apiary. The samples were stored at $-80{ }^{\circ} \mathrm{C}$ prior to examination. Thirty to 50 adult bees were randomly selected from each sample and were subjected to viral RNA isolation and subsequent RT-PCR analysis, as described previously (Grabensteiner et al. 2001;
Bakonyi et al. 2002; Berenyi et al. 2006; Forgách et al. 2008). For the detection of IAPV nucleic acid, two different RT-PCR assays were employed, one with the primers IABPV 3042f: ATTGAGAG TTGCCAAGGAGT and IABPV 3799r: GTCTGTGCTTCGATCACAAT (product length $758 \mathrm{bp}$ ), and the second assay with the primer pairs IABPV 6195f: TGTCGAGGAGGACTTGACAT and IABPV 6673r: GAAGCGAGTTCCGTATTGTG (product length $479 \mathrm{bp}$ ); the numbering of the primer names refers to the IAPV sequence with the GenBank accession number EF219380. The above-mentioned assays were established on the basis of positive reference material kindly provided by Prof. Sela (Rehovot, Israel). Specificity of the assays was confirmed by clear negative results obtained with $\mathrm{ABPV}$ and KBV reference samples. Reaction mixtures without RNA served as negative controls, and previously verified positive samples served as positive controls. Selected amplification products of each detected virus were sequenced. The nucleic acid sequences were analysed and compared with the corresponding sequences deposited in the GenBank database, National Center for Biotechnology Information (NCBI, http://www.ncbi.nlm.nih.gov), in order to confirm specificity of the amplicons.

Please note that to facilitate ease of reading, "virus detection" refers to "detection of viral nucleic acid" throughout the text.

\section{RESULTS}

Five honeybee viruses (ABPV, SBV, BQCV, DWV, and CBPV) were detected in the investigated Croatian bee samples (Table I, Figure 1). Results showed that $10.97 \%$ of investigated samples were infected with ABPV, 40.24\% with SBV, $29.26 \%$ with BQCV, $95.12 \%$ with DWV, and $9.75 \%$ with CBPV. No samples tested positive for KBV and IAPV. The highest percentage of infections was found for DWV, which occurred in 78 out of 82 apiaries. From all investigated samples, only one $(1.2 \%)$ did not contain any virus. In contrast, most of the samples were infected with more than one virus, i.e. in $1.2 \%$ of apiaries, four simultaneous virus infections were detected, and in $20.7 \%$ of samples, three different viruses were identified; 
Table I. Number of investigated samples and percentages of detected viruses in the various districts of Croatia.

\begin{tabular}{|c|c|c|c|c|c|c|c|c|c|}
\hline \multirow[t]{2}{*}{ No. } & \multirow{2}{*}{$\begin{array}{l}\text { Name of Croatian } \\
\text { district }\end{array}$} & \multirow{2}{*}{$\begin{array}{l}\text { No. of } \\
\text { samples }\end{array}$} & \multicolumn{7}{|c|}{ Percentage of positive samples } \\
\hline & & & ABPV & SBV & BQCV & DWV & $\mathrm{KBV}$ & CBPV & IAPV \\
\hline 1. & Bjelovarsko-bilogorska & 3 & 33 & 67 & 67 & 100 & - & - & - \\
\hline 2. & Brodsko-posavska & 1 & - & - & 100 & 100 & - & - & - \\
\hline 3. & Dubrovacko-neretvanska & 6 & - & 50 & 33 & 100 & - & 17 & - \\
\hline 4. & Istarska & 4 & - & 25 & - & 100 & - & - & - \\
\hline 5. & Karlovacka & 5 & 20 & 40 & 20 & 100 & - & - & - \\
\hline 6. & Koprivnicko-krizevacka & 10 & 16 & 40 & 30 & 100 & - & - & - \\
\hline 7. & Krapinsko-zagorska & 6 & - & - & 16 & 67 & - & 16 & - \\
\hline 8. & Licko-senjska & 1 & - & - & - & - & - & 100 & - \\
\hline 9. & Medjimurska & 3 & 33 & - & 33 & 100 & - & 33 & - \\
\hline 10 & Osjecko-baranjska & 3 & - & 100 & 33 & 100 & - & 33 & - \\
\hline 11. & Pozesko-slavonska & 5 & 20 & 40 & 40 & 100 & - & - & - \\
\hline 12. & Primorsko-goranska & 5 & - & 40 & 20 & 100 & - & - & - \\
\hline 13. & Sisacko-moslavacka & 5 & 20 & 80 & 20 & 100 & - & - & - \\
\hline 14. & Splitsko-dalmatinska & 4 & - & 25 & - & 100 & - & 25 & - \\
\hline 15. & Varazdinska & 3 & - & - & - & 100 & - & - & - \\
\hline 16. & Viroviticko-podravska & 3 & - & 67 & - & 67 & - & 33 & - \\
\hline 17. & Vukovarsko-srijemska & 2 & - & 50 & 50 & 100 & - & - & - \\
\hline 18. & Zadarska & 4 & - & 50 & 25 & 100 & - & 25 & - \\
\hline 19. & $\begin{array}{l}\text { Zagrebacka }+ \text { Town of } \\
\text { Zagreb }\end{array}$ & 6 & 50 & 33 & 50 & 100 & - & - & - \\
\hline 20 & Sibensko-kninska & 3 & - & 67 & 100 & 100 & - & - & - \\
\hline
\end{tabular}

$42.7 \%$ of apiaries showed double virus infections, and $35.7 \%$ were infected with only one virus. No significant regional differences in the distribution patterns of the various investigated viruses could be observed. The nucleotide sequences of the PCR products confirmed the specificity of the assays. The Croatian beevirus sequences exhibited 99 to $100 \%$ identity to corresponding sequences from other European countries.

\section{DISCUSSION}

The pathogenic potential of honeybee viruses has been realized for a long time (Bailey and Ball 1991). However, only during the last two decades has this potential been fully revealed in bee colonies, due to the emergence and spread of new parasites such as Varroa destructor (Rosenkranz et al. 2010; VanEngelsdorp and Meixner 2010) and Nosema ceranae (Dainat et al. 2012) in the European honeybee (Apis mellifera) populations. Furthermore, a number of other factors may be involved, too (Staveley et al. 2014). Altogether, this may lead to significant economic losses in beekeeping and agricultural production. Although epidemiological data on distribution and prevalence of honeybee viruses have been published from several European countries, there are still large areas, such as the Balkans, without published data. Viral bee diseases had not been systematically investigated in Croatia until recently, and this paper represents the first molecular evidence for the presence of honeybee viruses in Croatian apiaries. In this study we investigated 


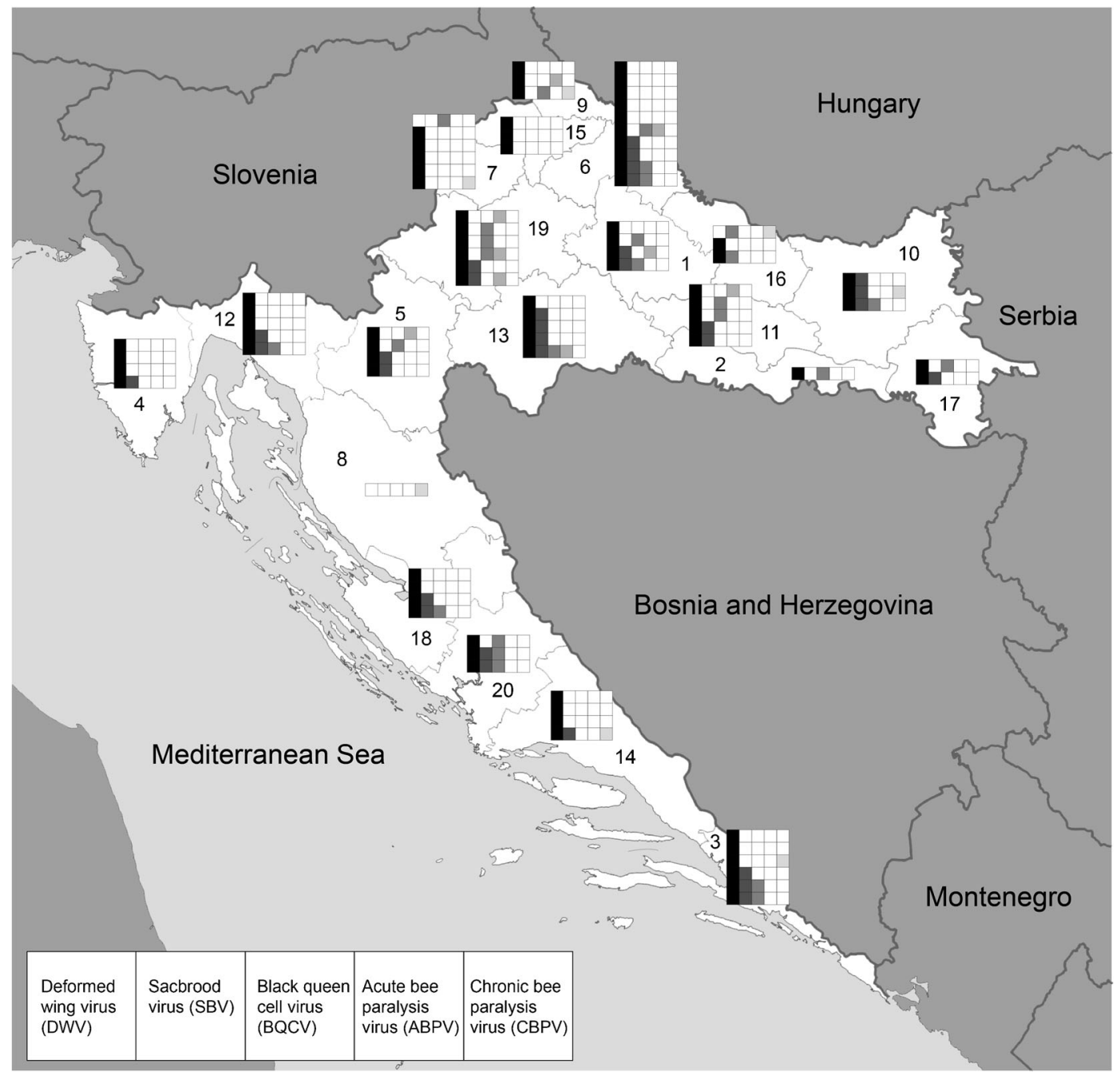

Figure 1 Distribution patterns of five different honeybee viruses detected in apiaries in all districts of Croatia. Since all samples tested negative for KBV and IAPV, these viruses are not displayed in the graph. The numbers shown in the different districts correspond to the names of the districts, as indicated in Table I. On the horizontal axis the five different viruses are shown, while the vertical axis represents the individual samples.

the occurrence, prevalence, and distribution patterns of the seven economically most important honeybee viruses in bee samples (winter losses) collected from apiaries located in all districts and climatic areas of Croatia. When comparing the prevalences detected during this study in Croatia to the corresponding results from some EU member states (Berenyi et al. 2006; Nielsen et al. 2008), the prevalences of BQCV, ABPV, SBV, and CBPV were generally lower in Croatia than in longer established EU member states, while the occurrence of DWV was similarly high $(>90 \%)$. A similar passive survey was performed in neighbouring Hungary 
in 2004. The occurrence of ABPV and BQCV was higher in that study, while SBV, CBPV, and DWV were less frequent (Forgách et al. 2008). We did not identify any infection with IAPV, which is distributed in Israel, Australia, and the USA (Chen and Evans 2007; Cox-Foster et al. 2007; Maori et al. 2007), and KBV, which has been detected in Asia, the USA, and Europe (Allen and Ball 1995; Siede and Büchler 2004; Tentcheva et al. 2004; Siede et al. 2005; Ward et al. 2007; de Miranda et al. 2010). Importation of honeybee colonies and bee queens from EU member states to Croatia has been rare due to strict regulations. This might be one reason for the lower prevalences of most of the investigated bee viruses. However, some parameters might have influenced the results, e.g. in this study mainly sick colonies were investigated ('passive survey') while in studies from other European countries healthy colonies were more frequently examined ('active survey'). Also, when investigating dead honeybees, as was partly done in this study, RNA degradation may occur in the samples, leading to false negative results.

This study is intended to constitute an epidemiological baseline regarding distribution patterns and prevalence of honeybee viruses in Croatia. Croatia is a new member state of the EU, and the-until recently-very restricted international trade with honeybees and bee products may change completely. Consequently - both for future importation and exportation-it is important to know the current status. Also, the diagnostic tools are now available in Croatia for further monitoring activities in order to reduce the risk of bee virus dispersal in so far moderately affected regions.

\section{ACKNOWLEDGMENTS}

The authors are grateful to the beekeepers for having kindly provided bee samples, to Prof. Sela (Rehovot, Israel) for IAPV-positive reference samples, and to Dr. Katharina Brugger (Vetmeduni Vienna, Austria) for the digital artwork. The Federation of European Microbiological Societies supported this work with a FEMS Research Fellowship for young scientists awarded to Ivana Tlak Gajger (no. 2010-1).

Prévalence et schémas de distribution de sept virus d'abeilles différents dans des colonies malades : une étude de cas en Croatie

\section{Apis mellifera / pertes hivernales / maladie virale /} RT-PCR

Prävalenz und Verbreitung von sieben unterschiedlichen Honigbienen-Viren in erkrankten Bienenvölkern : eine Fallstudie aus Kroatien

Apis mellifera / Winterverluste / Honigbienen-Viren / RT-PCR-Analyse / Krotaien

\section{REFERENCES}

Allen, M., Ball, B. (1995) Characterisation and serological relationship of strains of Kashmir bee virus. Ann. Appl. Biol. 126, 471-484

Allen, M., Ball, B. (1996) The incidence and world distribution of honey bee viruses. Bee World 77, 141-162

Antunez, K.A., D’Alessandro, B., Corbella, E., Ramallo, G., Zunino, P. (2006) Honeybee viruses in Uruguay. J. Invertebr. Pathol. 93, 67-70

Bailey, L. L., Ball, B. V. (1991) Honey bee pathology. Academic Press, 2nd edition. ISBN: 9780120734818.

Bailey, L., Perry, J.N. (2001) The natural control of the tracheal mite of honeybees. Exp. Appl. Biol. 103, 13-20

Bakonyi, T., Farkas, R., Szendroi, A., Dobos-Kovacs, M., Rusvai, M. (2002) Detection of acute bee paralysis virus by RT-PCR in honey bee and Varroa destructor field samples: rapid screening of representative Hungarian apiaries. Apidologie 33, 63-74

Berenyi, O., Bakonyi, T., Derakhshifar, I., Köglberger, H., Nowotny, N. (2006) Occurrence of six honeybee viruses in diseased Austrian apiaries. Appl. Environ. Microbiol. 72, 2414-2420

Chen, Y., Evans, J.D. (2007) Historical presence of Israeli acute paralysis virus in the United States. Am. Bee J. 147, 1027-1028

Chen, Y.P., Siede, R. (2007) Honey bee viruses. Adv. Virus Res. 70, 33-80

Cox-Foster, D.L., Conlan, S., Holmes, E.C., Palacois, G., Evans, J.D., et al. (2007) A metagenomic survey of microbes in honey bee colony collapse disorder. Science 318, 283-287 
Cresswell, J.E., Desneux, N., VanEngelsdorp, D. (2012) Dietary traces of neonicotinoid pesticides as a cause of population declines in honey bees: an evaluation by Hill's epidemiological criteria. Pest Manag. Sci. 68, 819-827. doi:10.1002/ps.3290

Dainat, B., Evans, J.D., Chen, Y.P., Gauthier, L., Neumann, P. (2012) Predictive markers of honey bee colony collapse. PLoS One. 7(2), e32151

De Miranda, J.R., Genersch, E. (2010) Deformed wing virus. J. Invertebr. Pathol. 103, 48-61

De Miranda, J.R., Cordoni, G., Budge, G. (2010) The Acute bee paralysis virus-Kashmir bee virus-Israeli acute paralysis virus complex. J Invertebr Pathol. 103(Suppl 1), S30-47

Delaplane, K.S., Mayer, D.F. (2000) Crop pollination by bees, pp. 352-352. CABI Publishing, New York USA

Forgách, P., Bakonyi, T., Tapaszti, Z., Nowotny, N., Rusvai, M. (2008) Prevalence of pathogenic bee viruses in Hungarian apiaries: situation before joining the European Union. J Invertebr Pathol. 98, 235-238

Gallai, N., Salles, J.M., Settele, J., Vaissière, B.E. (2008) Economic valuation of the vulnerability of world agriculture confronted with pollinator decline. Ecol. Econ. 68, 810-821

Genersch, E., Aubert, M. (2010) Emerging and reemerging viruses of the honey bee (Apis mellifera L.). Vet. Res. 41, 54-54

Grabensteiner, E., Ritter, W., Carter, M.J., Davison, S., Pechhacker, H., Kolodziejek, J., Boeking, O., Derakhshifar, I., Moosbeckhofer, R., Licek, E., Nowotny, N. (2001) Sacbrood virus of the honeybee (Apis mellifera): rapid identification and phylogenetic analysis using reverse transcription-PCR. Clin. Diagn. Lab. Immunol. 8, 93-104

Maori, E., Lavi, S., Mozes-Koch, R., Gantman, Y., Peretz, Y., Edelbaum, O., Tanne, E., Sela, I. (2007) Isolation and characterisation of Israeli acute paralysis virus, a dicistrovirus affecting honeybees in Israel: evidence for diversity due to intra- and interspecies recombination. J. Gen. Virol. 88, 3428-3438

Nielsen, S.L., Nicolaisen, M., Kryger, P. (2008) Incidence of acute bee paralysis virus, black queen cell virus, chronic bee paralysis virus, deformed wing virus, Kashmir bee virus and sacbrood virus in honey bees (Apis mellifera) in Denmark. Apidologie 39, 310-314

Nordstrom, S., Fries, I., Aarhus, A., Hansen, H., Korpela, S. (1999) Virus infections in Nordic honey bee colonies with no, low or severe Varroa jacobsoni infestations. Apidologie 30, 475-484

Ribière, M., Olivier, V., Blanchard, P. (2010) Chronic bee paralysis: A disease and a virus like no other? J. Invertebr. Pathol. 103, 120-131

Rosenkranz, P., Aumeier, P., Ziegelmann, B. (2010) Biology and control of Varroa destructor. J Invertebr Pathol. 103(Suppl 1), S96-119

Siede, R., Büchler, R. (2004) First detection of Kashmir bee virus in Hesse, Germany. Berl. Münch. Tierarztl. Wochenschr. 117, 12-15

Siede, R., Derakhshifar, I., Otten, C., Berenyi, O., Bakony, T., Köglberger, H., Büchler, R. (2005) Prevalence of Kashmir bee virus in central Europe. J. Apic. Res. 44, 129

Staveley, J.P., Law, S.A., Fairbrother, A., Menzie, C.A. (2014) A causal analysis of observed declines in managed honey bees (Apis mellifera). Hum Ecol Risk Assess. 20, 566-591

Tentcheva, D., Gauthier, L., Zappulla, N., Dainat, B., Cousserans, F., Colin, M.E., Bergoin, M. (2004) Prevalence and sesonal variations of six bee viruses in Apis mellifera L. and Varroa destructor mite populations in France. Appl. Environ. Microbiol. 70, 7185-7191

Todd, J.H., de Miranda, J.R., Ball, B.V. (2007) Incidence and molecular characterisation of viruses found in dying New Zealand honey bee (Apis mellifera) colonies infested with Varroa destructor. Apidologie 38, 354-367

VanEngelsdorp, D., Meixner, M.D. (2010) A historical review of managed honey bee populations in Europe and the United States and the factors that may affect them. J Invertebr Pathol. 103(Suppl 1), S80-95

Ward, L., Waite, R., Boonham, N., Fisher, T., Pescod, K., Thompson, H., Chantawannakul, P., Brown, M. (2007) First detection of Kashmir bee virus in the UK using real-time PCR. Apidologie 38, 181-190 